УДК 338.31

DOI: https://doi.org/10.26642/jen-2020-4(94)-22-28

О.В. Шавурська, к.е.н.

ВСП Житомирський торговельно-економічний фаховий коледж КНТЕУ

\title{
Оцінка ймовірності банкрутства як метод прогнозування фінансово-економічного стану підприємства
}

\begin{abstract}
Прогнозування банкрутства стає першочерговою необхідністю, щңо дасть можливість виявити основні проблеми $i$ недоліки в роботі підприємства, а також врахувати вплив різноманітних зовнішніх чинників, $і$ в результаті спрогнозувати ймовірність банкрутства та вжити заходів для його уникнення. Розглянуто економічну сутність поняття «банкрутство» та запропоновано власне визначення изього поняття, щчо враховує його економічний, соціальний та юридичний зміст. Охарактеризовано причини виникнення кризового стану на підприємстві. У кризових умовах функціонування вітчизняних підприємств важливим є уміння завчасно передбачити перші прояви фінансової неплатоспроможності, які в майбутньому можуть призвести до банкрутства, тому діагностика та запобігання негативним факторам $\epsilon$ актуальними. Визначено основні завдання аналізу діагностики банкрутства. Охарактеризовано зарубіжні та вітчизняні методи аналізу ймовірності настання банкрутства підприємства, визначено їх переваги, недоліки та можливість застосування. Запропоновано етапи економічного аналізу діагностики кризового стану та загрози банкрутства підприємства. На основі аналізу переваг і недоліків методик ймовірності банкрутства запропоновано інтегрований показник ймовірності банкрутства, щео дозволить визначити можливість існування загрози ймовірності банкрутства для вітчизняних підприємств. Інтегрований показник ймовірності банкрутства враховує всі основні показники фінансово-майнового стану підприємства, а його розрахунок дозволить своєчасно виявити загрозу ймовірності банкрутства.
\end{abstract}

Ключові слова: аналіз; банкрутство; неплатоспроможність; антикризове управління.

Актуальність теми. Кризова ситуація в Україні призвела до неплатоспроможності та банкрутства вітчизняних підприємств. У зв’язку з цим актуальними питаннями є діагностика банкрутства та здійснення антикризового управління з метою його попередження. Діагностика банкрутства має бути спрямована на недопущення виникнення кризової ситуації, її виявлення, а також прийняття відповідних управлінських рішень щодо іiі уникнення. Антикризове управління націлене на покращення фінансових показників діяльності підприємства, а також зменшення витрат. Тому актуальними є дослідження, що спрямовані на виведення підприємств зі стану кризи або їх ліквідації.

Аналіз останніх досліджень і публікацій показав, що проблематиці банкрутства присвячені праці багатьох вітчизняних науковців, зокрема: О.Я. Базілінської, І.О. Бланка, В.О. Подольської, Н.П. Шморгун, А.М. Штангрета та ін. Діагностика банкрутства детально описана такими вченими, як О.Б. Андрушко, О.В. Гук, Н.І. Коломієць, К.Л. Ларіонова, О.О. Терещенко, О.О. Шапурова. Проте подальшого дослідження потребують такі проблемні питання: визначення факторів впливу на ймовірність банкрутства підприємства та удосконалення методичного забезпечення діагностики банкротства.

Метою статті $\epsilon$ обгрунтування рекомендацій щодо теоретичних основ банкрутства та удосконалення методичного забезпечення економічного аналізу діагностики банкротства.

Викладення основного матеріалу. Зростання кількості збиткових підприємств, а також нестабільні умови господарювання, призводять до того, що питання банкрутства підприємств є актуальним. У сьогоднішніх карантинних умовах банкрутство $є$ поширеним явищем, що має соціально-економічний та юридичний аспекти, адже його наслідки поширюються на всі сфери суспільного життя.

Банкрутство є невід’ємною частиною будь-якої економіки, оскільки дозволяє, 3 одного боку, «відсіяти» неефективні підприємства, а з другого - сприяє оздоровленню суб'єктів господарювання, які зазнали тимчасових фінансових труднощів [1].

У світовій практиці законодавство про банкрутство розвивалося за двома принципово різними моделями. За британською моделлю банкрутство розглядається як засіб повернення боргів кредиторам, що передбачає ліквідацію боржника. А американська модель спрямована на недопущення банкрутства та полягає у відновленні його платоспроможності. Проте останнім часом у законодавстві розвинутих країн спостерігається тенденція до поєднання обох моделей.

Штангрет А.М. вважає, що законодавство про неплатоспроможність має бути спрямоване на розробку заходів з відновлення платоспроможності боржника, або, як у випадку неможливості уникнення ліквідації, на проведення справедливого розподілу майнових збитків серед усіх суб'єктів права, чиї інтереси можуть бути обгрунтовані неплатоспроможністю боржника [11, с. 310]. 
Серед основних причин банкрутства варто виокремити порушення фінансової стійкості підприємства (перевищення зобов'язань над активами), незбалансованість грошових потоків (переважання негативного грошового потоку), тривалу неплатоспроможність підприємства, низьку ліквідність активів.

Проведений аналіз економічної літератури показав, що існують різні підходи щодо визначення поняття «банкрутство». У цілому можна констатувати, що процедура банкрутства є кінцевою стадією невдалого функціонування підприємства. Запропоновано розглядати банкрутство в трьох аспектах (юридичному, економічному та соціальному) (рис. 1).

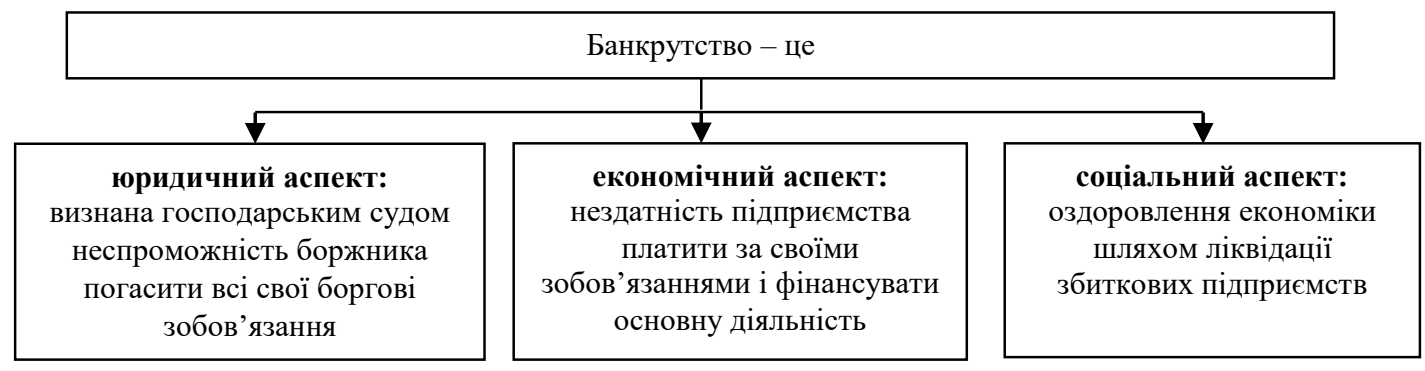

\section{Рис. 1. Запропонований підхід до трактування поняття «банкрутство» (розробка автора)}

Позитивні сторони соціального аспекту банкрутства проявляються в:

- закритті нерентабельних виробництв, що дає змогу зменшити витрати і підвищити ефективність суспільного виробництва; вивільненні залучених до неконкурентоспроможних виробництв ресурсів;

- оздоровленні економіки шляхом ліквідації неефективних підприємств.

Проте найбільше на економіку впливають недоліки банкрутства, зокрема:

- втрата значних коштів, вкладених кредиторами у збанкрутіле підприємство;

- зростання безробіття та загострення соціальної напруженості у суспільстві;

- зниження дохідної частини бюджету через зменшення податків;

- зниження загального потенціалу економічного розвитку країни.

Процедура банкрутства регламентується багатьма державними нормативними актами. Крім того, на міжнародному рівні є законодавчі акти, що регулюють певні питання, пов'язані з фінансової безпекою суб'єктів господарювання, зокрема Європейська конвенція «Про деякі міжнародні аспекти банкрутства» [3]. Критеріями абсолютної неплатоспроможності є беззаперечні грошові вимоги кредитора(ів) в сумі не менше 300 мінімальних розмірів заробітної плати та строк прострочення розрахунків - три місяці 3 встановленого дня їх погашення [8].

Проблему існування фіктивного та умисного банкрутства слід шукати у недосконалості та неузгодженості норм чинного законодавства. Так у ст. 215 Господарського кодексу України дається визначення понять фіктивного та умисного банкрутства. Фіктивним банкрутством визнається завідомо неправдива заява суб'єкта підприємництва до суду про нездатність виконати зобов'язання перед кредиторами та державою. Умисним банкрутством визнається стійка неплатоспроможність суб'єкта підприємництва, викликана цілеспрямованими діями власника майна та посадової особи суб'єкта підприємництва, якщо це завдало істотної матеріальної шкоди інтересам держави, суспільства чи інтересам кредиторів, що охороняються законом [3].

Головною метою чинної нормативно-правової бази, що врегульовує процедури банкрутства, перш за все, є відновлення платоспроможності боржника, а не його ліквідація та розподіл наявного майна між кредиторами. У багатьох розвинених країнах пріоритет належить саме санаційним (реорганізаційним) процедурам, спрямованим на збереження кожного суб'єкта господарювання, відродження його потенціалу. Тільки такий підхід за умов суцільної кризи, яка здебільшого спровокована зовнішніми факторами, визнається єдино можливим та забезпечує відродження економічного потенціалу України.

Вид банкрутства безпосередньо залежить від істинної причини його виникнення. Тому детального вивчення потребує питання причин виникнення банкрутства та розробки конкретних шляхів його недопущення. Провівши порівняльний аналіз щодо визначення основних факторів, що впливають на банкрутство, нами вони були згруповані в таблиці 1.

Таким чином, зовнішніх i внутрішніх чинників, що призводять до виникнення банкрутства підприємства, існує безліч, тому їх слід об’єднати в групи, що дозволить своєчасно їх ідентифікувати та нейтралізувати. Крім того, погоджуємося із думкою О.В. Гук, що систематизація факторів виникнення кризових явищ створює об'єктивні підстави для формування ефективної антикризової політики [4].

Зовнішні причини виникнення банкрутства можна в цілому об'єднати у такі групи факторів, як економічні (макроекономічна нестабільність, спад виробництва, інфляція), політичні (політична нестабільність держави), правові (недосконалість господарського та податкового законодавства), 
демографічні (структура та рівень добробуту населення, зменшення купівельної спроможності населення), природні (стихійні лиха та природні катаклізми).

Щодо внутрішніх факторів, що зумовлюють виникнення банкрутства, найбільш доцільним вважаємо таке групування факторів: виробничі (неефективне використання ресурсів, дефіцит власних оборотних засобів, низький рівень організації виробництва), управління (низька якість менеджменту, блокування інновацій та раціоналізаторства), планування (недосконалість механізму ціноутворення, значна питома вага непродуктивних витрат), організації (бездіяльність юридичних служб підприємства) та контролю (відсутність контролю за договірними відносинами, нерозвинутість фінансового контролінгу).

Таблиця 1

Основні фактори (причини) виникнення банкрутства

\begin{tabular}{|c|c|c|}
\hline Автор & Екзогенні чинники & Ендогенні чинники \\
\hline $\begin{array}{c}\text { Базілінська О.Я. } \\
\text { [1] }\end{array}$ & $\begin{array}{l}\text { - макроекономічна нестабільність; } \\
\text { - значний рівень інфляції; } \\
\text { - сезонні коливання; } \\
\text { - посилення монополізму на ринку; } \\
\text { - дискримінація підприємства } \\
\text { органами влади та управління; } \\
\text { - погіршення криміногенної ситуації }\end{array}$ & $\begin{array}{l}\text { - неефективність інвестиційної та } \\
\text { фінансової діяльностей; } \\
\text { - низька якість менеджменту; } \\
\text { - рівень кваліфікації персоналу; } \\
\text { - блокування раціоналізаторства; } \\
\text { - нерозвинутість фінансового } \\
\text { контролінгу тощо }\end{array}$ \\
\hline $\begin{array}{c}\text { Проценко Н.Б. } \\
\text { [9] }\end{array}$ & $\begin{array}{l}\text { - зменшення купівельної спроможності } \\
\text { населення; } \\
\text { - нестабільність податкового } \\
\text { законодавства; } \\
\text { - посилення конкуренції в галузі; } \\
\text { - політична нестабільність у країні } \\
\text { місцезнаходження підприємства або в } \\
\text { країнах підприємств-постачальників } \\
\text { (споживачів продукції) }\end{array}$ & $\begin{array}{l}\text { - дефіцит в організаційній структурі; } \\
\text { - недоліки у виробничій сфері; } \\
\text { - прорахунки в галузі постачання; } \\
\text { - низький рівень маркетингу; } \\
\text { - втрата ринків збуту продукції; } \\
\text { - дефіцит у фінансуванні }\end{array}$ \\
\hline $\begin{array}{c}\text { Шморгун П.Н. } \\
\text { [11] }\end{array}$ & $\begin{array}{l}\text { - кризовий стан економіки: інфляція, } \\
\text { загальний спад виробництва, } \\
\text { нестабільність фінансової системи, } \\
\text { зростання цін на ресурси; } \\
\text { - зміна кон’юнктури ринку; } \\
\text { - неплатоспроможність партнерів; } \\
\text { - високий рівень податків; } \\
\text { - нестабільна політична ситуація в } \\
\text { країні; } \\
\text { - антимонопольна політика країни; } \\
\text { - неудосконаленість законодавства; } \\
\text { - зміна чисельності та складу } \\
\text { населення; } \\
\text { - рівень та структура споживання; } \\
\text { - життєвий рівень та } \\
\text { платоспроможність населення; } \\
\text { - стихійне лихо тощо }\end{array}$ & $\begin{array}{l}\text { - низький рівень техніки, технології та } \\
\text { організації виробництва; } \\
\text { - виробництво неконкурентоспроможної } \\
\text { продукції; } \\
\text { - зниження ефективності використання } \\
\text { виробничих ресурсів і потужностей; } \\
\text { - створення понаднормових залишків } \\
\text { запасів; } \\
\text { - уповільнення обіговості капіталу, } \\
\text { створення його дефіциту; } \\
\text { - використання позик на невигідних } \\
\text { умовах; } \\
\text { - збільшення фінансових витрат; } \\
\text {-зниження показників рентабельності; } \\
\text { - погана клієнтура підприємства, що } \\
\text { платить із запізненням або не платить і } \\
\text { веде до ланцюгового банкрутства; } \\
\text { - відсутність портфеля замовлень, що } \\
\text { веде до зменшення обсягів реалізації }\end{array}$ \\
\hline
\end{tabular}

Довідка: узагальнено автором на основі $[1,9,11]$

Підсумовуючи дані, встановлено, що існує значна кількість внутрішніх і зовнішніх факторів неплатоспроможності. Тому керівництво підприємства має вміти їх виявляти 3 метою уникнення неплатоспроможності у майбутньому.

У кризових умовах функціонування вітчизняних підприємств важливим $є$ уміння завчасно передбачити перші прояви фінансової неплатоспроможності, які в майбутньому можуть призвести до банкрутства, тому діагностика та запобігання негативним факторам є актуальними. До завдань аналізу передумов неплатоспроможності та банкрутства підприємства належать:

- оцінка результатів господарської діяльності за попередні та поточний роки;

- виявлення факторів, які позитивно чи негативно вплинули на показники діяльності підприємства;

- оцінка структури балансу; 
- оцінка фінансового стану неплатоспроможного підприємства;

- розробка варіантів та організаційних процедур щодо можливості подальшої діяльності підприємства.

Перші спроби проведення аналізу діяльності фірм-банкрутів були зроблені в 30-ті роки А.Винокором і Р.Смітом; у найбільш завершеному вигляді методика і техніка прогнозування банкрутства висвітлені у роботах Е.Альтмана, який здійснював діагностику банкрутства компаній, що передбачала розрахунок фінансової стійкості підприємства та прогнозування показників на майбутній період.

Прогнозування банкрутства як самостійна проблема виникла у США після закінчення II світової війни. Це було пов'язано зі зростання кількості підприємств, що збанкрутували у зв'язку зі скороченням військових замовлень. Перші серйозні спроби розробити ефективну методику прогнозування банкрутства були в 1960-х рр. та пов'язані з розвитком комп'ютерної техніки [7].

На основі проведеного аналізу наукових статей встановлено, що методи діагностики банкрутства поділяють на дві групи. До першої групи належать методи, що базуються на розрахунку і аналізі системи фінансових показників (методика У.Бівера, метод кредитного скорингу Д.Дюрана; метод Ж.Депаляна; методика діагностики банкрутства підприємства I.А. Бланка та ін.) [3].

Методи другої групи передбачають використання дискримінантного аналізу, сутність якого полягає у тому, що за допомогою математично-статистичних методів будують функцію і розраховують інтегральний показник, на підставі якого можна 3 достатньою ймовірністю передбачити банкрутство суб'єкта господарювання [10].

Система діагностики кризового стану та ймовірності банкрутства підприємства містить ряд етапів, які дозволяють зробити висновок про існування загроз в діяльності підприємства та визначити ймовірність його банкрутства. Вважаємо, що в системі антикризового управління доцільно застосовувати таку послідовність діагностики банкрутства підприємства (рис. 2).

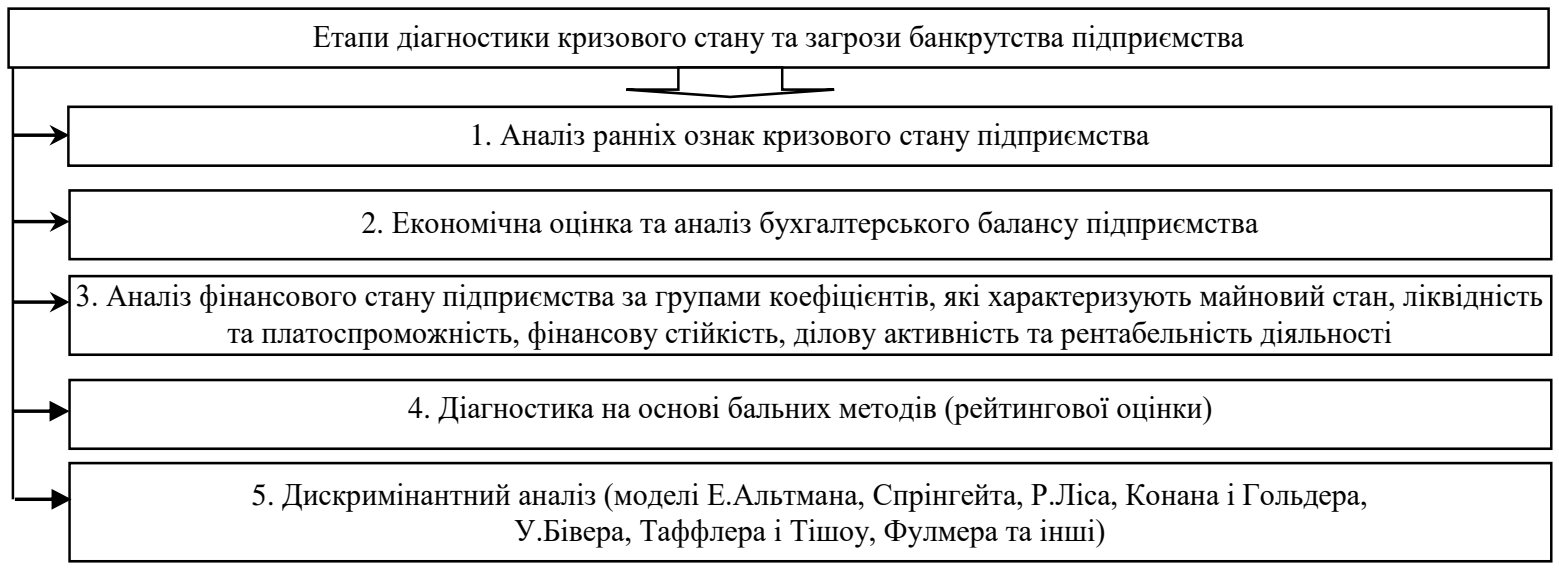

\section{Рис. 2. Етапи діагностики кризового стану та загрози банкрутства підприємства (розробка автора)}

Згідно з запропонованою етапністю проведення діагностики банкрутства, першим її етапом $є$ аналіз ранніх ознак кризового стану підприємства. Проведення діагностики банкрутства за ранніми сигналами передбачає аналіз якісних показників.

Підсумовуючи вказане, слід зауважити, що всі моделі містять набір різних показників, мають територіальну специфіку. Визначено основні проблеми адаптації зарубіжних моделей банкрутства до вітчизняної практики:

1) відсутність інформації про базу розрахунку вагових значень коефіцієнтів моделі та про базу розрахунку критеріїв оцінки отриманих результатів моделі;

2) відсутність статистики банкрутств українських підприємств, яка могла б підтвердити чи спростувати надійність моделі;

3) застосування моделей ускладнюється проблемою достовірності інформації вітчизняних звітів, оскільки підприємства застосовують рівні методичні підходи щодо формування звітних показників. Усе вказане вище свідчить про те, що спроби використати зазначені моделі для українських підприємств навряд чи виявляться успішними і дадуть надійні результати [10].

На основі проведених досліджень та опрацьованих матеріалів нами були згруповані основні переваги та недоліки закордонних моделей визначення ймовірності банкрутства, що наведені в таблиці 2. 
Переваги та недоліки закордонних моделей визначення ймовірності банкрутства

\begin{tabular}{|c|c|}
\hline 1. & \\
\hline $\begin{array}{l}\text { 1. Моделі містять велику кількість } \\
\text { показників, що забезпечує низьку } \\
\text { трудомісткість іх використання при } \\
\text { достатньо високій точності результатів; } \\
\text { 2. Моделі передбачають інтегральну } \\
\text { оцінку і дають можливість порівняння } \\
\text { стану піяльності } \\
\text { підприємства; } \\
\text { 3. Інформація для розрахунку всіх } \\
\text { показників доступна і міститься в } \\
\text { основних формах фінансової звітності; } \\
\text { 4. Існує можливість не тільки } \\
\text { прогнозування банкрутства, але й оцінка } \\
\text { зони ризику, в якій знаходиться } \\
\text { підприємство; } \\
\text { 5. Моделі мають високу ймовірність } \\
\text { оцінювання і досить дієві на практиці; } \\
\text { 6. Деякі моделі можна використовувати } \\
\text { для підтвердження результатів як } \\
\text { окремо, так і в сукупності; } \\
\text { 7. Найбільш адаптована до української } \\
\text { практики модифікована м модель } \\
\text { Е.Альтмана та Р.Таффлера }\end{array}$ & $\begin{array}{l}\text { 1. Моделі використовувалися та визначалися на основі } \\
\text { західноєвропейських підприємств, а будь-яка країна має } \\
\text { свою специфіку; } \\
\text { 2. Моделі не адаптовані до вітчизняної економіки і не } \\
\text { враховують більшості важливих показників (розвитку } \\
\text { галузі, стану постачальників та конкурентів, доходів та } \\
\text { витрат, споживачів); } \\
\text { 3. У розрахункових коефіцієнтах немає найважливіших } \\
\text { показників діяльності підприємства; } \\
\text { 4. Моделі враховують тільки балансові показники та } \\
\text { показники Звіту про фінансові результати; } \\
\text { 5. Моделі наводяться з різними за вагомістю показниками, } \\
\text { що обумовлено розходженнями в бухгалтерському обліку } \\
\text { окремих показників, впливом інфляції на їх формуванн, } \\
\text { невідповідністю балансової та ринкової вартості окремих } \\
\text { активів та інших об'єктивних причин; } \\
\text { 6. Деякі з методичних підходів суперечать один одному, } \\
\text { оскільки при одночасному їх застосуванні аналітик може } \\
\text { отримати протилежні результати } \\
\text { 7. Неможливо точно визначити ймовірність банкрутства } \\
\text { та й показники для оцінки вибрані невдало, оскільки } \\
\text { підприємства з найгіршими показниками покриття та } \\
\text { автономії все одно можуть вдало працювати і отримувати } \\
\text { прибуток; } \\
\text { 8. Моделі не враховують специфіки діяльності } \\
\text { підприємства залежно від галузі; } \\
\text { 9. Відсутність статистики українських підприємств- } \\
\text { банкрутів, яка могла б підтвердити чи спростувати } \\
\text { надійність моделі }\end{array}$ \\
\hline
\end{tabular}

Довідка: узагальнено автором на основі $[1,6,10,12]$

Необхідно адаптовувати закордонні моделі визначення ймовірності банкрутства до практики в Україні. Терещенко О.О. розробив власну модель визначення неплатоспроможності для вітчизняних компаній. Особливістю методики є те, що вона має дещо зміщені оцінки. У ній зроблено акцент на зменшенні помилкового зарахування фінансово неспроможних підприємств до групи стійких. Така асиметричність має за мету убезпечити інвестора від ризикового вкладення коштів, але знижує точність прогнозу в цілому. Іншим суттєвим недоліком цієї моделі $є$ широкий інтервал невизначеності нормативних оцінок [1].

На основі аналізу переваг і недоліків методик ймовірності банкрутства запропоновано інтегрований показник ймовірності банкрутства, що дозволить визначити можливість існування загрози ймовірності банкрутства для вітчизняних підприємств:

$$
I=K_{n}+K_{a}+K_{\text {smp.ns. }}+K_{\phi 3},
$$

де $I$ - інтегрований показник ймовірності банкрутства;

$K_{n}$ - коефіцієнт покриття;

$K_{a}$ - коефіцієнт автономії;

$K_{\text {вmp.nл }}$ - коефіцієнт втрати платоспроможності;

$K_{\phi з}-$ коефіцієнт фінансової залежності.

Враховуючи оптимальні значення вказаних вище коефіцієнтів, вважаємо, що якщо I становить до 1, у такому випадку ймовірність банкрутства підприємства надзвичайно висока і може відбутися протягом року. Якщо $I$ знаходиться в межах від 1 до 2,5, у такому випадку ймовірність банкрутства підприємства висока і може відбутися протягом трьох років. Якщо I. становить від 2,51 до 3,5 - ймовірність банкрутства підприємства низька і може відбутися протягом п'яти років. У випадку перевищення I за 3,51 ймовірність банкрутства низька.

Вважаємо, що запропонований інтегрований показник ймовірності банкрутства враховує всі основні показники фінансово-майнового стану підприємства, а його розрахунок дозволить своєчасно виявити загрозу ймовірності банкрутства підприємства. 
Висновки та перспективи подальших досліджень. Введення обмежень щодо здійснення господарської діяльності в 2020 році в Україні стало однією з причин банкрутства частини підприємств і організацій. Від рішень керівництва суб'єкта господарювання залежить ефективність функціонування. Тому необхідно ідентифікувати основні фактори, що впливають на підприємство, та розробити раціональні способи реагування на зовнішні впливи ризику, обумовленого невизначеністю зовнішнього середовища. Адже чим більше невизначеностей, тим більший ризик, тим складніше приймати ефективні рішення. Прогнозування банкрутства дозволяє виявити ключові проблеми в роботі підприємства та ідентифікувати вплив чинників зовнішнього середовища, i в кінцевому підсумку спрогнозувати ймовірність банкрутства та прийняти заходи для його уникнення.

Доведено, що банкрутство є складним процесом, який можна розглядати з різних сторін - юридичної (визнана господарським судом неспроможність боржника погасити всі боргові зобов'язання); економічної (нездатність оплатити зобов'язання) та соціальної (ліквідація збиткових підприємств, що призводить до зростання безробіття).

Проведений аналіз існуючих методичних підходів щодо визначення ймовірності банкрутства підприємств дозволив виокремити основні та найбільш інформативні показники, які найчастіше використовуються у розрахунках за дискримінантними моделями з метою виявлення кризового стану діяльності підприємства та попередження його банкрутства, а саме: чистий прибуток, власний капітал, дохід (виручка) від реалізації, активи, запозичений капітал. На основі аналізу переваг і недоліків методик ймовірності банкрутства запропоновано інтегрований показник ймовірності банкрутства, який враховує всі основні показники фінансово-майнового стану підприємства, а його розрахунок дозволить своєчасно виявити загрозу ймовірності банкрутства.

\section{Список використаної літератури:}

1. Барановський O.I. Фінансові кризи: передумови, наслідки і шляхи запобігання : монографія / O.I. Барановський. - К. : Київ. нац. торг.-екон. ун-т, 2009. - 753 с.

2. Бланк I.О. Фінансове забезпечення розвитку підприємств / І.О. Бланк, Г.В. Ситник та ін. ; за ред. проф. I.О. Бланка. - К. : КНТЕУ, 2011. - 344 с.

3. Господарський Кодекс України від 16 січня 2003 року № 436-IV зі змінами та доповненнями [Електронний pecypc]. - Режим доступу : http://zakon.rada.gov.ua/cgi-bin/laws/main.cgi?nreg=436-15.

4. Гук O.В. Фінансова криза на підприємстві: причини, наслідки та способи подолання / О.В. Гук // Вісник Хмельницького національного університету. Економічні науки. - 2016. - № 2, Т. 2. - С. 230-235.

5. Європейська конвенція «Про деякі міжнародні аспекти банкрутства»: станом на 5 червня 1990 р. [Електронний ресурс]. - Режим доступу : http://zakon2.rada.gov.ua.

6. Іващенко О.В. Діагностика банкрутства підприємства / О.В. Іващенко, О.І. Крисак // Держава і регіони. 2016. - № 5. - С. 129-131.

7. Перерва П.Г. Банкротство, санація та реструктуризація підприємства як економічні категорії антикризового управління / П.Г. Перерва // Вісник Національного технічного університету «ХПІ». Серія : Технічний прогрес та ефективність виробництва : зб. наук. пр. - 2015. - № 59 (1168). - С. 148-152.

8. Про відновлення платоспроможності боржника або визнання його банкрутом : Закон України від 14 травня 1992 р. № 2343-XII (у редакції від 4 квітня 2018 р.) / Верховна Рада України [Електронний ресурс]. - Режим доступу : http://search.ligazakon.ua/__doc2.nsf/link1/T234300.html.

9. Проценко Н.Б. Методичні підходи до прогнозування діяльності підприємств в аспекті забезпечення їх стійкого функціонування. / Н.Б. Проценко // Статистика України. - 2007. - № 4. - С. 70-73.

10. Трои I.B. Формування системи попередження, прогнозування і подолання банкрутства промислових підприємств / I.B. Трои // Економіка: реалії часу : науковий журнал. - 2015. - № 4 (20). - С. 272-278.

11. Штангрет A.M. Формування організаційного потенціалу як основа забезпечення економічної безпеки підприємства / A.M. Штангрет // Наукові записки Української академії друкарства. - 2014. - № 3 (48). C. $28-33$.

12. Штангрет А.М. Процес здійснення обліково-аналітичного забезпечення управління економічною безпекою підприємства / А.М. Штангрет // Наукові записки Української академії друкарства. Серія : Економічні науки. - 2015. - № 2. - С. 15-22.

\section{References:}

1. Baranovs'kyj, O.I. (2009), Financial crises: preconditions, consequences and ways of prevention, monograph, Kyiv. nat. trade and economy University, Kyiv, 753 p.

2. Blank, I.O. and Sytnyk, G.V. et al. (2011), Financial support of enterprise development, in prof. Blank, I.O. (ed.), KNTEU, K., $344 \mathrm{p}$

3. Economic Code of Ukraine, January 16, 2003 No. 436-IV with changes and additions, [Online], available at: http://zakon.rada.gov.ua/cgi-bin/laws/main.cgi?nreg=436-15

4. Guk, O.V. (2016), «Financial crisis in the enterprise: causes, consequences and ways to overcome», Bulletin of Khmelnytsky National University. Economic sciences, No. 2, Vol. 2, pp. 230-235.

5. European Convention on Certain International Aspects of Bankruptcy: as of June 5, 1990, [Online], available at: http://zakon2.rada.gov.ua 
6. Ivashhenko, O.V. and Krysak, O.I. (2016), «Diagnostics of enterprise bankruptcy», State and Regions, No. 5, pp. 129-131.

7. Pererva, P.G. (2015), «Bankruptcy, reorganization and restructuring of the enterprise as economic categories of crisis management», Bulletin of the National Technical University «KhPI». Series Technical progress and production efficiency, Coll. Science. pr., No. 59 (1168), pp. 148-152.

8. VRU (1992), On restoring the solvency of the debtor or declaring him bankrupt, Law of Ukraine of May 14, 1992 No. 2343-XII (as amended on April 4, 2018) [Online], available at: http://search.ligazakon.ua/1_doc2.nsf/link1/T234300.html

9. Procenko, N.B. (2007), «Methodical approaches to forecasting the activities of enterprises in terms of ensuring their sustainable operation», Statistics of Ukraine, No. 4, pp. 70-73.

10. Troc, I.V. (2015), «Formation of the system of prevention, forecasting and overcoming of bankruptcy of industrial enterprises», Economics: the realities of time. Scientific journal, No. 4 (20), pp. 272-278.

11. Shtangret, A.M. (2014), «Formation of organizational potential as a basis for economic security of the enterprise», Scientific notes of the Ukrainian Academy of Printing, No. 3 (48), pp. 28-33.

12. Shtangret, A.M. (2015), «The process of accounting and analytical management of economic security of the enterprise», Scientific notes of the Ukrainian Academy of Printing, Series Economic Sciences, No. 2, pp. 15-22.

Шавурська Олена В’ячеславівна - кандидат економічних наук ВСП Житомирський торговельноекономічний фаховий коледж КНТЕУ.

Наукові інтереси:

- обліково-аналітичне забезпечення сталого лісокористування;

- економічний аналіз діяльності підприємств;

- антикризове управління. 